\title{
Imposing Application of Nano Cellulose Based Bio Sensor to Produce Test Kit of COVID: 19 Disease
}

\author{
Redwanul Hasan ${ }^{1 *}$, Minhazul Islam Minhaz ${ }^{1}$ and Sazid H Shipan ${ }^{2}$ \\ ${ }^{1}$ Department of Yarn Engineering, Bangladesh University of Textiles, Bangladesh \\ ${ }^{2}$ Departemnt of Industrial Production Engineering, Bangladesh University of Textiles, Bangladesh
}

*Corresponding author: Redwanul Hasan, Department of Yarn Engineering, Bangladesh University of Textiles, Bangladesh.

Received Date: May 27, 2020

Published Date: June 10, 2020

\begin{abstract}
This article reflects that probable application of Nano cellulose to invent test kit of COVID: 19 diseases. It is recognized that COVID: 19 is a pandemic disease. Novel Corona virus is a mRNA virus which is enveloped by protein molecules. In the structure of corona virus, it contains protein spikes. In this conceptual article, the author predicts that Nano cellulose based test kit can detect corona virus positive in the human body. Cellulose is one of the most abundant biomass in the world. In the structure of cellulose there are lots of hydroxyl ion remain. Hydroxyl ion can give reaction with the amino acid. Authors wanted to develop a process model to make the test kit of COVID: 19 diseases. Wood is the best source of cellulose. Besides its, textile materials like cotton, flax etc are another good source of cellulose. In this article, the source of cellulose cannot play a vital role .The method of processing cellulose Nano device \& reaction mechanism between hydroxyl ion \& amino acid will play a significant role.
\end{abstract}

Keywords: Nanocellulsoe; Biosensors; Chromatography; Device; Point of care; Sustainable, Piezoelectric, Electrode, Electrophoresis

\section{Introduction}

Actually Nanocellulsoe is a promising natural material which is extracted from natural cellulosic source. There are varieties types of Nanocellulsoe. Like cellulose nanocrystal, Nanocellulsoe filament, bacterial cellulose is remaining in the research area. In this article author used Nano cellulose to produce test kit of COVID: 19 diseases. COVID: 19 is a pandemic disease in this world. There is a crisis of test kit in this world. This proposed model helps to experiment about the test kit. Nanocellulose is a cost effective advanced material which is used for biodegradability \& low cytotoxicity. Advanced Nanocellulsoe was used for producing test kit of HIV virus, Ebola virus \& hepatitis C virus [1].Professor Whiteside's research group invented cellulose based point of care molecular devices at Harvard University [1]. Prediction goes that this process is applicable for making test kit of COVID: 19 diseases. Cellulose is a sustainable material source which can be extracted from cotton, wood, bacteria. Nanocellulose has a great mechanical characteristics .Actually the mechanical characteristics depend on the source of extraction [3].

\section{Structural Analysis of Novel Corona Virus}

Corona virus has four genera.They are: alpha corona virus, beta corona virus, gamma corona virus\& delta corona virus. Alpha \& beta corona virus create infection to the mammals. Gamma corona virus can affect the avian species. Delta corona virus can infect both mammals \& avian species. Corona virus is a large enveloped, positive standard RNA virus. The genome sequence is $27-32 \mathrm{~KB}$. In the structure of corona virus helical capsid is surrounded by nucelocapsid protein. There are three types of protein in novel corona virus. Membrane protein, envelope protein, spikes protein (Figure 1). 


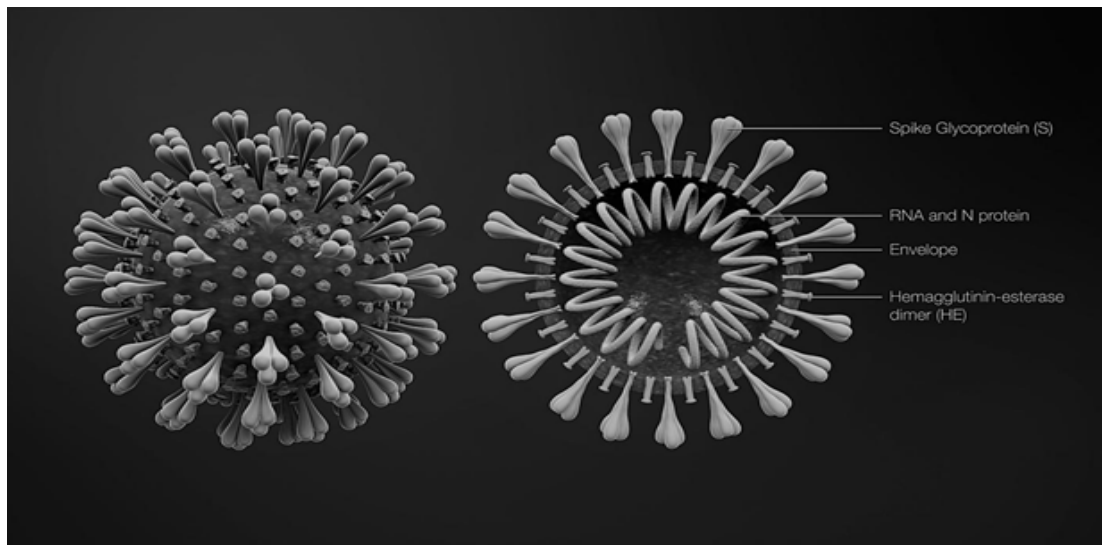

Figure 1: Structure of Novel Corona Virus [2].

From the observation of American National Institute of Health spike protein is tractable to boggle hole the human cells to produce COVID: 19 diseases [2]. This proposed model can help to identify spike protein of novel corona virus . Proposed test kit can identify spike protein from insulating antibodies of people .Schematic diagram of SARS-COV-2 virus (novel corona) virus is given below (Figure 2):

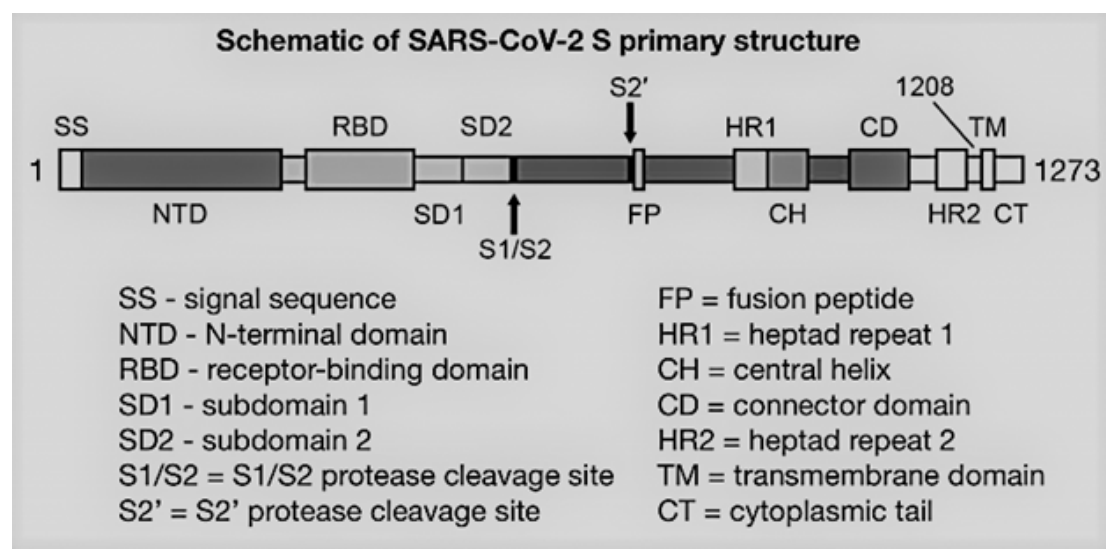

Figure 2: Schematic primary structure of novel corona virus [2].

\section{Nanocellulose Based Biosensor}

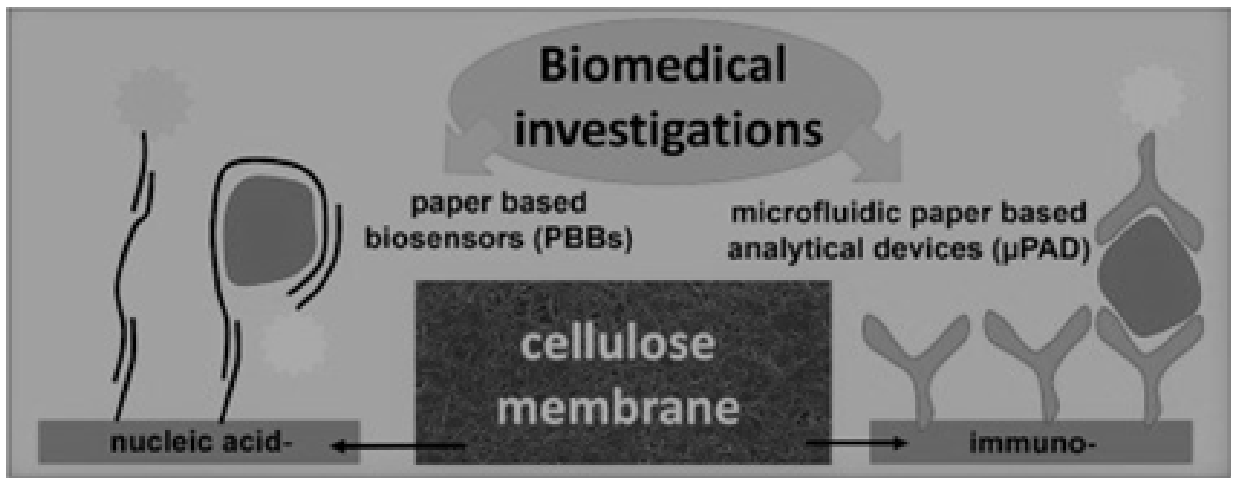

Figure 3: Modified Nano cellulose membrane to biomedical investigation [1]. 
Besides the biomedical application of Nano cellulose has been used for some special functions. One of the functions is detecting the disease or acting as a diagnostic device. Actually it is a cellulose based device which is called point of care molecular device. These systems are low cost, lightweight, hydrophilic \& porous. This device is revealed by renewable material \& rehashes them to appropriate compact lab - on systems. The device is originally disclosed by the stamping patterns, channels \& trial zones by involving a fragment of paper. The process of this Nano cellulose based point of core medical device is giving a biological sample like blood, urine \& saliva are applied to the diagnosis media through a special device. The paper collisions the sample through the ducts to trial zones to mode the biochemical reaction. It is known to all Nano cellulose is a piezoelectric material [4]. It can change its electrical polarization during mechanical stress. The sensors are generally joined by sandwiching Nano cellulose between two electrodes. Due to piezoelectric approach, when blood, saliva etc are given in the trial zone an external force is created to the Nano cellulose film, then it changes electrical polarization \& getting signal by sandwiched sensors. Finally chromatography method is used to diagnosis the disease (Figure 3).

\section{Biochemical Reaction of Amino acid of Spike Protein \& Hydroxyl ion of Nanocellulose}

We all know that the PH of blood is 7.4. It's a basic medium actually. When the patient will give the blood in Nano cellulose based device, it takes reaction between amino acid of spike protein \& hydroxyl group of Nano cellulose. As blood is a basic medium reaction will be occurred following way (Figure 4).

$$
\mathrm{NH}_{3}++\mathrm{OH}-\rightarrow \mathrm{NH}_{2}+\mathrm{H}_{2} \mathrm{O}
$$

I

$\mathrm{R}-\mathrm{CH}-\mathrm{COO}-$

I

\section{$\mathrm{R}-\mathrm{CH}-\mathrm{COO}-$}

\section{(This is a negative ion, not a zwitter ion)}

Figure 4: Biochemical reaction between amino acid of spike protein \& hydroxyl group of Nanocellulsoe.

Here amino acid is existed in a negative ion employing electrophoresis. Electrophoresis is composed of morsel of moistened filter paper on a microscopic slide. A drop of amino acid solution is located in the centre of the paper.

\section{Proposed Flow Chart of Nanocellulose Based Biosensor Test Kit for detecting COVID: 19 Disease}

It is known to all that, Fast Protein Liquid Chromatography is the process which is used to analyze or purify proteins. As in the other forms of chromatography, separation of protein is possible here. It is possible because the different components of a mixture have different affinities for two materials. There is a two phase of fluid here. One is the mobile phase and another one is stationary phase. In this case, blood cell protein is the mobile phase fluid \& Spike protein of novel corona virus is stationary phase protein [5]. In FPLC, (Fast Protein Liquid Chromatography) mobile phase protein is recognized as running "buffer" solution. The common strategy of "Fast Protein Liquid Chromatography" is there are two buffer solution. One is running buffer \& another one is stationary buffer. At first a mixture containing one or more proteins are dissolved in running buffer solution \& this column should be pumped. Another column is stationary buffer solution. Columns are large in size. Columns diameter are $\mathrm{mm}$ in size range. Columns are composed of inert plastic or inert fluid materials like Teflon, titanium and glasses. Columns are stored by $24 \%$ ethanol or H2O. In this case, affinity based FPLC should be proposed. In affinity chromatography, separate based protein which has highly specific interaction among antigen \& antibody, enzyme \& substrate or receptor \& ligand. Total 10 instruments are used for separating protein by fast protein liquid chromatography system $[6,7]$.

\section{Stationary phase}

It is mainly a resin based agarose beads with varying surface ligand. Here Spike protein of novel corona virus is stationary phase protein.

\section{Mobile phase}

Generally buffer solutions \& organic solvents are recognized as mobile phase protein. Here, blood cell protein is nominated as mobile phase protein.

\section{Pump}

Pump is used to control constant flow of fluid.

\section{Mixer}

Mixer is an important element which maintains the relative proportion of buffer solutions during the period of FPLC (Fast protein Liquid Chromatography) runs. 


\section{Injection Valve}

Pumps are connected by valves due to controlling direction of buffer solution

\section{Column}

There are two types of column which are mentioned above. The capacity of column pressure is 580 psi.

\section{Fraction collector}

It can be allowed volume at fraction level.

\section{Flow restrictor}

It can produce a steady back pressure to disclose air bubbles which is originated by flow cells of columns.

\section{On - line filter}

It can reject sample particles by creating maximum back pressure of $0.5 \mathrm{Mpa}$.

\section{Detection system}

Ultra violet spectro photometer, conductivity detector \& refractive index (RI) based detector can use to separate protein by detecting the specific protein (Figure 5).

After separating spike protein \& blood cell protein changing color of Nano cellulose based test kit can give the COVID: 19 positive or negative results. The total flow process is given below:
Nanocellulose based Spike protein Sensing Biosensor

$\downarrow$

Biochemical reaction occurs between amino acid of spike protein \& hydroxyl ion of Nanocellulsoe

$\downarrow$

Fast Protein Liquid Chromatography procedure is used to apart the corona virus spike protein from

Blood cell protein

$\downarrow$

Finally changing the color of test kit will give the result of COVID: 19 positive or negative

$\downarrow$

If the test kit is not shown any color change, COVID: 19 tests will be negative

$\downarrow$

If the test kit is shown any colored spot, COVID: 19 tests will be positive

After separating spike protein from blood cell protein the Nanocellulsoe based test kit will be dissolved in ninhydrin solution. If it can change its color or create a spot, COVID: 19 tests will positive. If it does not change its color or create any colored spot, COVID: 19 tests will negative [8-10].

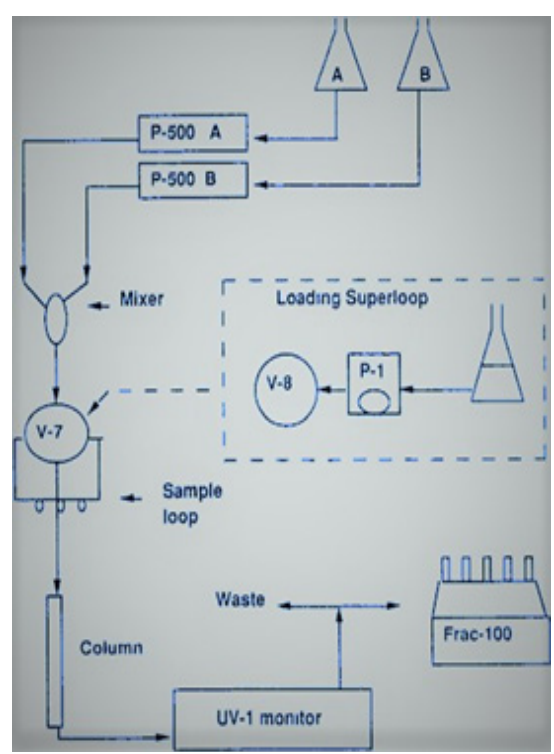

Figure 5: Process flow of Fast protein Liquid Chromatography [16].

\section{Conclusion}

This article gleams the proposed model of Nanocellulsoe based biosensor test kit for diagnosing COVID: 19 diseases. Now a day's people are suffering very badly in COVID: 19 diseases
[11-15]. The affected rate is increasing day by day. Actually it is a conceptual paper which gives a idea to coin a test kit for detecting the disease. Here spike protein is separated from antibodies by the guidance of American national institute of health [2]. The genome 
sequence is not taken any consider to produce test kit because here spike protein of novel corona virus should be separated. Genome sequence has not any consequence to produce test kit. COVID: 19 is a potential threat for the larger community of the world. Rapid test kit can help to diagnosis the disease \& people to get rid of this lethargic life. In fine, this paper will beget a new horizon for the COVID: 19 disease related research activities [15-20].

\section{Acknowledgement}

Authors are very much acknowledged to department of Yarn Engineering, Bangladesh University of Textiles.

\section{Conflict of Interest}

Authors declare no conflict of interest.

\section{References}

1. Jorfi M, Foster EJ (2014) Recent advances in nanocellulose for biomedical application. Journal of Applied Polymer Science 132(14): 41719.

2. Rota PA, Oberste MS, Monroe SS, Nix WA, Campagnoli R,et al. (2003) Characterization of a novel corona virus associated with severe acute respiratory syndrome. Science 300(5624): 1394-1399.

3. Lin N, Durfresene A (2014) Nanocellulose in biomedicine: current status and future. European Polymer Journal 59: 302-325.

4. Tukkanen S, Rajala S (2018) Nanocellulose as a piezoelectric material. IntechOpen.

5. Li F (2016) Structure, Function and evolution of corona virus spike proteins. Annual Reviews of Virology 3: 237-261.

6. Dumanli AG (2016) Nanocellulose and its composites for biomedical application. Curr Med Chem 24(5): 512-528.

7. Lu R, Zhao X, Li J, Niu P, Yang B, et al. (2020) Genomic characterization and epidemiology of 2019 novel corona virus :implications for virus origins and receptor binding. Lancet 395(10224): 565-574.

8. Woo-Chan JF, Hang-Kok K (2020) Genomic characterization of the 2019 novel human -pathogenic corona virus isolated from a patient with atypical pneumonia after visiting Wuhan. Emerging Microbes and Infections: 9.

9. Shi Z, Philips GO, Yang G (2013) Nanocellulose electorconductive composities. Nanoscale 5: 3194-3201.
10. Jogalekar MP, Veerabathini A, Gangadaran P (2020) Novel 2019 corona virus: genome structure, clinical trials and outstanding questions. Exp Biol Med.

11. Hänninen A, Sarlin E, Lyyra I, Salpavaara T, Kellomäki M, et al. (2015) Nanocellulose and chitosan based films as low cost, green piezoelectric material. Carbohydrate Polymers 202: 418-424.

12. Galmohammadi H, Morales-Narvaez E, Nagdi T, Merkoci A (2017) Nanocellulose in sensing and biosensing. Chemistry of Materials 29(13): 5426-5446.

13. Yan C, Wang J, Kang W, Cui M, Wang X, et al. (2014) Highly stretchable piezoresistive Graphene-nanocellulose nanopaper for strain Sensors. Advanced Materials 26(13): 2022-2027.

14. Csoka L, Hoeger IC, Rojas OJ, Peszlen I, Pawlak JJ, et al. (2012) Piezoelectric effect of cellulose nanocrystals thin films. ACS Marco letters 1(7): 867-870.

15. Choi HY, Jeong YG (2018) Mirostructures and piezoelectric performance of eco-friendly composite films based on nanocellulose and barium titanate nanoparticle.Composites Part B Engineering 168: 58-65.

16. Kunz C, Lönnerdal B (1989) Human milk Proteins: Separation of whey proteins and their analysis by Polyacrylamide gel electrophoresis, fast protein liquid chromatography (FPLC) gel filtration,and anion -exchange chromatography. The American Journal of Clinical nutrition. 49(3): 464470 .

17. Heleno SA, Barros L, Sousa MJ, Martins A, Ferreria IC (2009) Study and characterization of selected nutrients in wild mushrooms from portugal by gas chromatography and high performance liquid chromatography. Microchemical Journal 93(2): 195-199.

18. Hollar CM, Law AJR, Dalgleish DG, Medrano JF. Brown RJ (1991) Separation of $\beta$ casein A1, A2 and B using cation -exchange fast protein liquid chromatography. Journal of Diary Science 74(10): 3308-3313.

19. Girardet JM, Mati A, Sanogo T, Etienne L (1991) Fast protein liquid chromatography purification of hydrophobic fraction of bovine milk proteose -peptone and characterization by bidimensional electrophoresis. Journal of Dairy Science 58(1): 85-98.

20. Haginaka J (2008) Recent progress in protein -based chiral stationary phases for enantioseparations in liquid chromatography. Journal of Chromatography B 875(1): 12-19. 